\title{
PERANCANGAN PUSAT PENELITIAN DAN PENGEMBANGAN TANAMAN HUTAN TROPIS BERBASIS EDUKASI DI KOTA BOGOR
}

\author{
Hernawati', Atie Ernawati ${ }^{2}$, Ryan Hidayat ${ }^{3}$ \\ ${ }^{1}$ Universitas Indraprasta PGRI, Program Studi Arsitektur \\ hernawatiher99@gmail.com \\ ${ }^{2}$ Universitas Indraprasta PGRI, Program Studi Arsitektur \\ atie.ernawati@unindra.ac,id, atie2373@gmail.com \\ 3 Universitas Indraprasta PGRI, Program Studi Arsitektur \\ ryansastra3@gmail.com
}

\begin{tabular}{|c|c|c|}
\hline \multicolumn{2}{|c|}{ Informasi artikel } & ABSTRAK \\
\hline \multicolumn{2}{|l|}{ Sejarah } & \multirow{6}{*}{$\begin{array}{l}\text { Kota Bogor memiliki hutan seluas } 282.58 \text { ha yang teridentifikasi sebagai hutan } \\
\text { kota. Sekitar } 2,3 \% \text { lahan di Kota Bogor ditanami oleh tanaman hutan. Adanya } \\
\text { hutan yang cukup luas di Kota Bogor, memerlukan adanya perhatian lebih dalam } \\
\text { pemeliharaan dan pengembangan pada hutan tersebut. Salah satu upaya } \\
\text { pemeliharaan dan pengembangan hutan di Kota Bogor yaitu dengan } \\
\text { memfasilitasi kegiatan penelitian dan pengembangan tanaman hutan itu sendiri. }\end{array}$} \\
\hline \multicolumn{2}{|l|}{ artikel: } & \\
\hline Diterima & 28 September 2021 & \\
\hline Revisi & 29 September 2021 & \\
\hline Dipublikasikan & 30 September 2021 & \\
\hline \multicolumn{2}{|l|}{ Kata kunci: } & \\
\hline \multicolumn{2}{|l|}{ Penelitian } & Selain kegiatan penelitian, bangunan juga harus dapat menunjang kegiatan \\
\hline \multicolumn{2}{|l|}{ Edukasi } & edukasi bagi masyarakat agar seluruh lapisan masyarakat dapat teredukasi \\
\hline \multicolumn{2}{|l|}{ Laboratorium } & dalam memelihara dan menjaga hutan. Oleh karena itu dalam menunjang \\
\hline \multicolumn{2}{|c|}{ Arsitektur Ekologi } & $\begin{array}{l}\text { kegiatan edukasi tentang tanaman hutan, maka akan dirancang Pusat Penelitian } \\
\text { dan Pengembangan Tanaman Hutan Tropis berbasis edukasi di Kota Bogor. }\end{array}$ \\
\hline
\end{tabular}

Key word:

Research

Education

Laboratory

Ecology Architecture

\begin{abstract}
Bogor City has a forest area of 282.58 ha which is identified as urban forest. Around $2.3 \%$ of the land in Bogor City is planted with forest plantations. The existence of a fairly large forest in the city of Bogor, requires more attention in the maintenance and development of the forest. One of the efforts to maintain and develop forests in Bogor City is to facilitate research and development of forest plants themselves. In addition to research activities, buildings must also be able to support educational activities for the community so that all levels of society can be educated in maintaining and protecting forests. Therefore, to support educational activities about forest plants, an education-based Tropical Forest Plant Research and Development Center will be designed in Bogor City.
\end{abstract}

\section{PENDAHULUAN}

Paradigma global pembangunan kehutanan telah mengalami pergeseran yang nyata, dari eksploitasi hutan alam menuju budidaya hutan tanaman yang didukung oleh hasil riset dan perkembangan teknologi dengan memperhatikan kelestarian hutan alam. Budidaya tanaman hutan untuk memenuhi berbagai keperluan sudah dimulai sejak lama. Di beberapa negara bahkan telah menggeser peran hutan alam baik untuk memasok bahan baku industri maupun non industri. Sampai saat ini hutan tanaman di seluruh dunia sudah mencapai 264 juta hektar, 46,49\% diantaranya berada di hutan tropis Asia atau 6,6\% dari luas hutan alam dunia. Indonesia berkontribusi 1,87\% atau 4,9 juta hektar. (Leksono, 2011)

Di Indonesia, program hutan tanaman secara intensif baru mulai dilakukan setelah PP No. 7 tahun 1990 tentang Hak Pengusahaan Hutan Tanaman Industri (HPHTI) diberlakukan. Target pembangunan HTI di seluruh Indonesia pada tahun 2000 adalah seluas 6,2 juta hektar. Seluas 4,4 juta hektar di luar Jawa, dan 1,8 juta hektar di Jawa. Target produksi kayu adalah 90 juta m3/tahun3 . Setelah berjalan 10 tahun sejak ditetapkannya, realisasi penanaman hanya 23,55\% atau 1,85 juta hektar dengan riap volume yang dihasilkan masih jauh dari target4 . Dengan demikian, tahap awal ini program pembangunan HTI di Indonesia mengalami kegagalan. Indonesia mempunyai kekayaan 
hayati yang sangat melimpah dengan mempunyai 30.000 lebih jenis tanaman obat yang tumbuh (Aserani, 2010)

Center for International Forestry Research (CIFOR) merupakan salah satu bangunan penelitian tentang tanaman hutan yang berada di Hutan Penelitian Dramaga, Kota Bogor. CIFOR merupakan pusat penelitian yang dibentuk oleh organisasi sektor swasta dan masyarakat dengan tujuan untuk memperbaiki sistem pemanfaatan sumberdaya alam dan bidang pertanian tanpa menyebabkan kerusakan lingkungan, serta upaya dalam rangka menanggulangi bahaya kelaparan. CIFOR juga bergabung dengan beberapa bangunan kemitraan yaitu Consultative Group on International Agricultural Research (CGIAR), World Agroforestry Centre (ICRAF) dan bangunan dari pemerintahan.

CIFOR juga terbuka bagi orang-orang atau pelajar yang ingin melakukan penelitian tentang tanaman hutan, tetapi dalam kenyataannya cukup sulit mendapatkan akses masuk ke dalamnya serta tidak adanya bangunan khusus sebagai penunjang kegiatan edukasi. Oleh karena itu dalam menunjang kegiatan edukasi tentang tanaman hutan, maka akan dirancang Pusat Penelitian dan Pengembangan Tanaman Hutan Tropis dengan tema hutan. Tema rancangan ini tidak terlepas dari Arsitektur Ekologis sebagai metode pendekatan perancangan. Arsitektur Ekologis diharapkan dapat menciptakan hubungan yang seimbang dan selaras antara manusia dengan lingkungan alam sekitar. Prinsip-prinsip Arsitektur Ekologis akan menjadi dasar dalam pembentukan konsep-konsep perancangan.

Pusat Penelitian dan Pengembangan Tanaman Hutan Tropis merupakan re-desain atau pengembangan dari CIFOR. Proses re-desain ini juga merupakan upaya pengelolaan kawasan Hutan Penelitian Dramaga sebagai eko wisata yang menarik di Kota Bogor. berdasarkan latar belakang di atas, tujuan rancangan ini yaitu merancang Pusat Penelitian dan Pengembangan Tanaman Hutan Tropis Berbasis Edukasi di Kota Bogor. Pusat penelitian dan pengembangan ini merupakan bangunan yang menunjang kegiatan riset, pengembangan, produksi, dan pemasaran bibit tanaman hutan tropis. Fasilitas dalam kegiatan riset berupa laboratorium, kantor pengelola, kantor pemasaran, green house, nursery, dan kebun percobaan. Dengan fasilitas penunjang untuk edukasi berupa gallery, auditorium, perpustakaan, ruang multimedia, dan ruang workshop yang dapat dikunjungi oleh masyarakat umum.

\section{METODOLOGI}

Terdapat dua teknik pengumpulan data yaitu primer dan sekunder. Teknik pengumpulan data primer dapat diperoleh dari observasi, wawancara, dokumentasi dan analisis data. Sedangkan teknik pengumpulan data sekunder dapat diperoleh dari berbagai sumber seperti buku, jurnal, laporan dan sebagainya.

Berdasarkan sifat, penulis menggunakan data kualitatif yaitu data yang disajikan dalam bentuk kata-kata (tulisan), gambar (audio) atau video yang memiliki makna. Data-data tersebut diperoleh dari wawancara, pengamatan, pemotretan, perekaman dan lain-lain.

\section{HASIL DAN PEMBAHASAN \\ Lokasi Proyek}

Lokasi perancangan proyek berada di kawasan Hutan Penelitian Dramaga, tepatnya di Jl. Raya Cifor, RT.03/RW.05, Situgede, Kec. Bogor Barat, Kota Bogor, Jawa Barat 16115. Hutan Penelitian Dramaga ini merupakan hutan yang dikelola khusus sebagai hutan penelitian. Hutan ini berada di tengah-tengah pemukiman warga dan di kelilingi banyak instansi pendidikan penelitian terkait seperti sekolah, universitas serta rumah sakit. 
Pemilihan site disini karena pemerintah Kota Bogor dan Kementerian Lingkungan Hidup dan Kehutanan (KLHK) selaku pengelola menginginkan kawasan Situ Gede dan Cifor menjadi kawasan wisata andalan Kota Bogor masa depan. Langkah itu menjadi upaya untuk menarik wisatawan ke Kota Bogor.

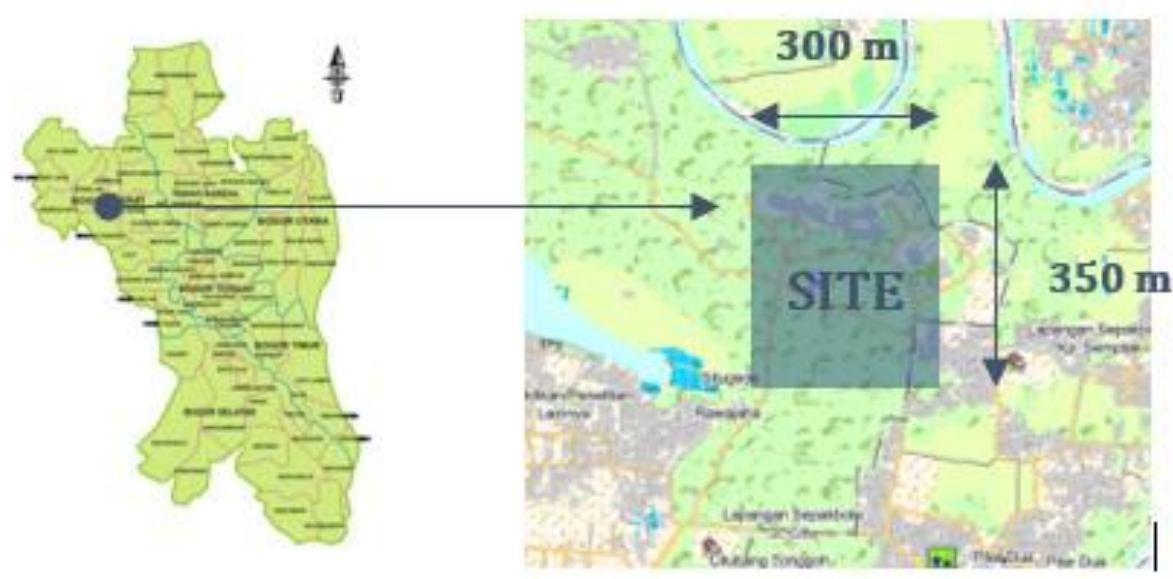

Gambar 1. Lokasi Tapak

1. Peruntukan : Pusat Penelitian dan Pengembangan

2. Luas Tapak $: 10.500 \mathrm{~m}^{2} / 10,5 \mathrm{Ha}$

3. KDB $: 60 \%$

4. KLB $: 2$

\section{Analisis Tapak}

\section{Batasan Site}

Site merupakan lahan Cifor yang akan mengalami re-desain. Site berada di Hutan Penelitian Dramaga yang dikelilingi pemukiman dan banyak instansi pendidikan penelitian terkait seperti sekolah, universitas serta rumah sakit.

Batasan Site :

$\begin{array}{ll}\text { Batas Utara } & \text { : Sungai Cisadane } \\ \text { Batas Selatan } & \text { : Perumahan warga } \\ \text { Batas Timur } & \text { : Perumahan warga } \\ \text { Batas Barat } & \text { : Perumahan warga }\end{array}$

\section{Kondisi Eksisting Tapak}

Lokasi site yang di gunakan berada di Jl. Raya Cifor, Situgede, Kec. Bogor Barat, Kota Bogor, Jawa Barat. Lokasi site berada di kawasan Hutan Penelitian Dramaga seluas 52 hektar yang dikelola oleh CIFOR (Center for International Forestry Research). CIFOR merupakan pusat penelitian yang dibentuk oleh organisasi sektor swasta dan masyarakat dengan tujuan untuk memperbaiki sistem pemanfaatan sumberdaya alam dan bidang pertanian tanpa menyebabkan kerusakan lingkungan, serta upaya dalam rangka menanggulangi bahaya kelaparan. 


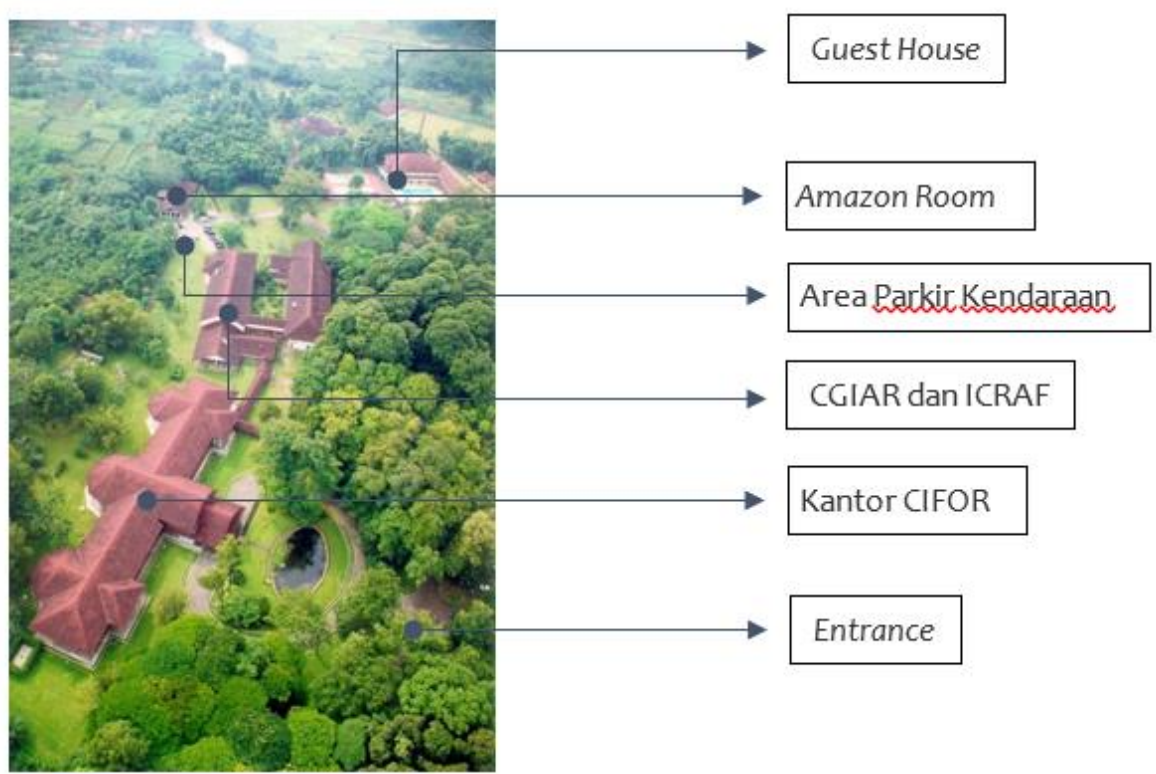

Gambar 2. Kantor Cifor

Pemilihan site disini karena pemerintah Kota Bogor dan Kementerian Lingkungan Hidup dan Kehutanan (KLHK) selaku pengelola menginginkan kawasan Situ Gede dan Cifor menjadi kawasan wisata andalan Kota Bogor masa depan. Langkah itu menjadi upaya untuk menarik wisatawan ke Kota Bogor.

Hutan Penelitian Dramaga ini merupakan hutan yang dikelola khusus sebagai hutan penelitian. Hutan ini berada di tengah-tengah pemukiman warga dan di kelilingi banyak instansi pendidikan penelitian terkait seperti sekolah, universitas serta rumah sakit.

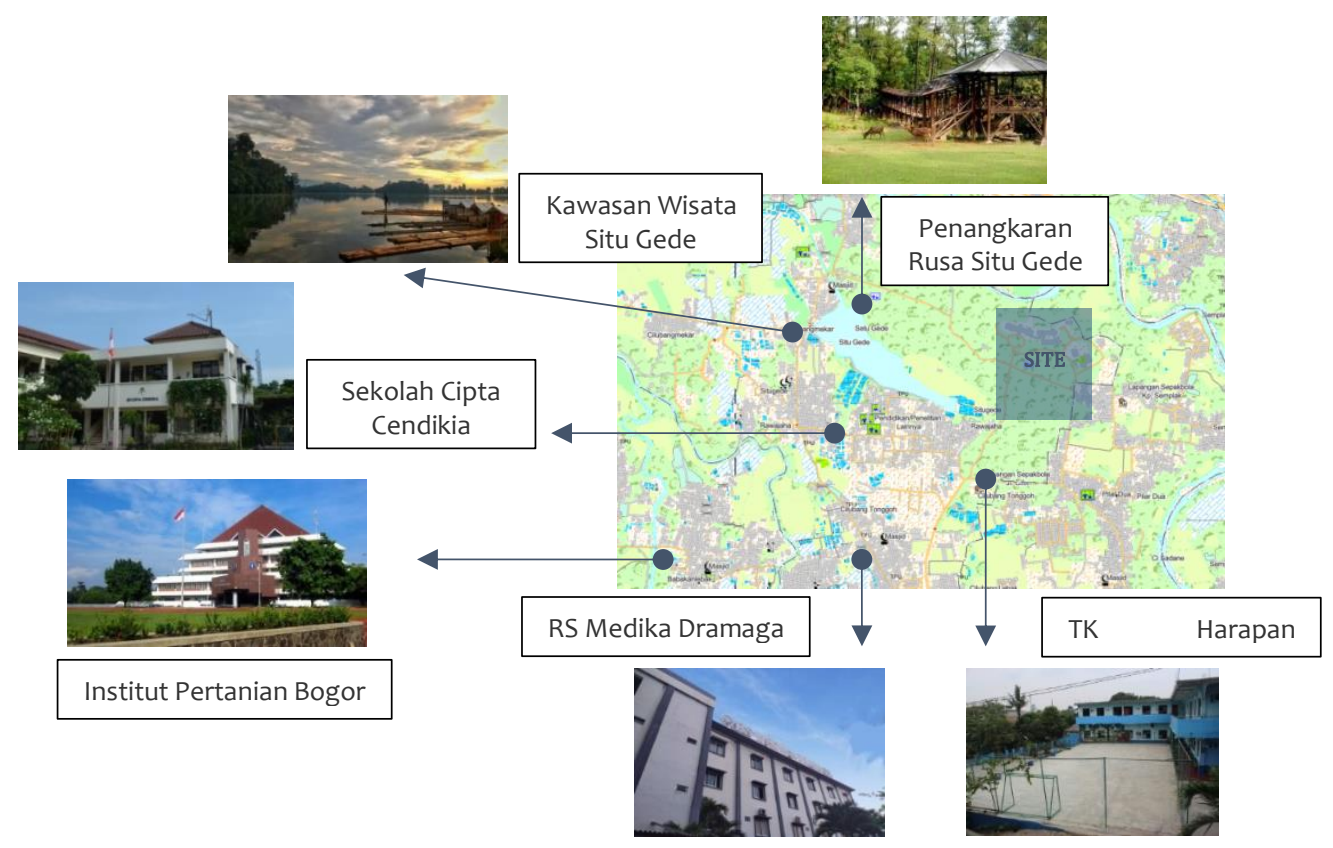

Gambar 3. Bangunan Sekitar Site 


\section{Konfigurasi Tapak}

Kondisi tapak memiliki bentuk yang simetris dan cenderung memiliki komposisi yang seimbang, sehingga memudahkan dalam pemanfaatan lahan.

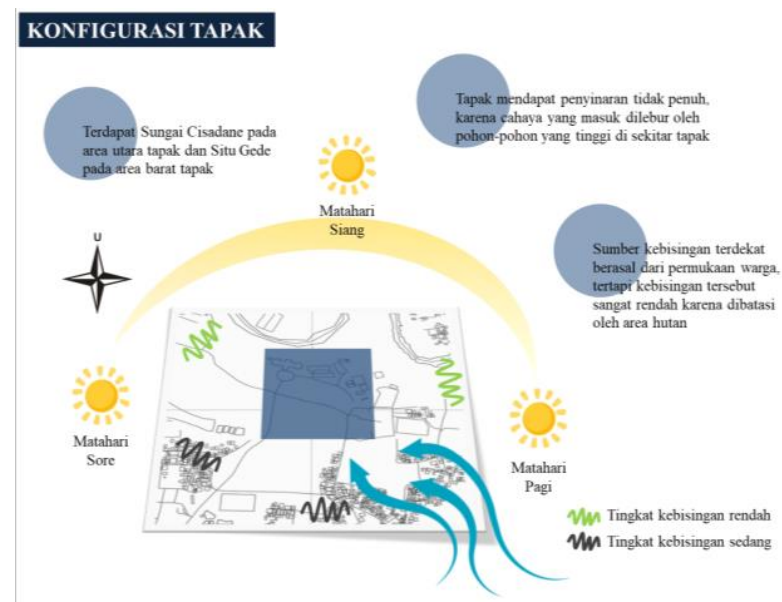

Gambar 4. Konfigurasi Tapak

\section{Pencapaian}

Untuk mencapai tapak dapat dilalui dengan berjalan kaki, bersepeda, kendaraan motor, mobil dan bus. Akses menuju tapak sudah cukup baik dengan jalan selebar 8 meter yang telah diaspal. Lokasi tapak dapat akses dari Stasiun Kota Bogor dengan jarak 7,5 km dan dari Terminal Baranagsiang dapat ditempuh dengan jarak 10,1 km.

Tabel 1. Pencapaian Tapak

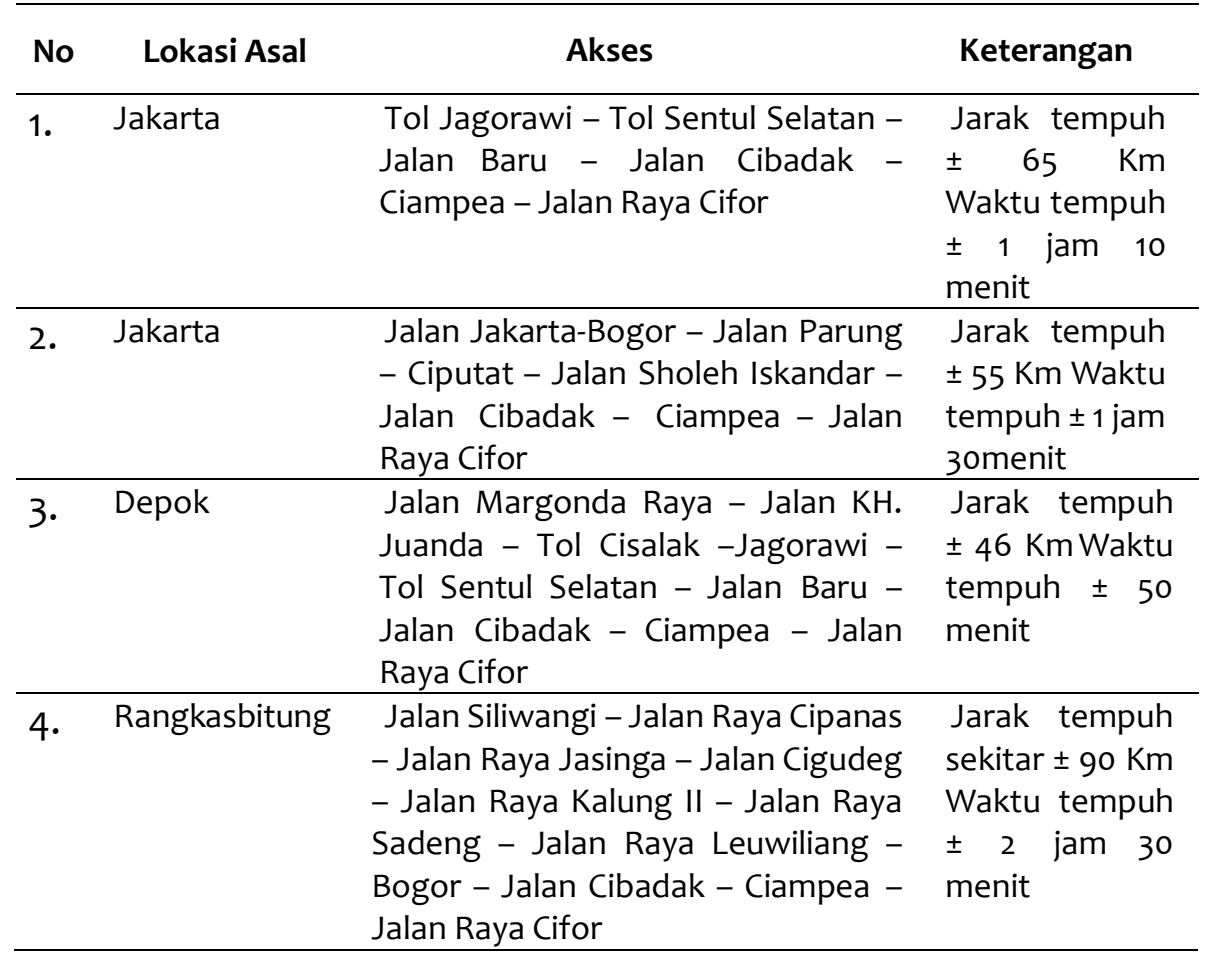


138 Perancangan Pusat Penelitian dan Pengembangan Tanaman Hutan Tropis Berbasis Edukasi di Kota Bogor

\begin{tabular}{lll}
\hline 5. Sukabumi & Jalan Raya Siliwangi - Jalan Raya Jarak tempuh \\
& Sukaraja - Sukabumi - Jalan Raya \pm 62 Km Waktu \\
& Cibadak - Sukabumi - Jalan Raya tempuh \pm 1 jam \\
& Bogor - Sukabumi - Jalan Ruas 3omenit \\
& Bogor - Ciawi - Sukabumi - Jalan \\
& Tol Jagorawi - Jalan Sholeh \\
& Iskandar - Jalan Cibadak - Ciampea \\
& - Jalan Raya Cifor \\
\hline
\end{tabular}

\section{Analilis Iklim}

Menurut klasifikasi Schmidt dan Ferguson ( 1951 ), tipe iklim di Hutan Penelitian Dramaga adalah termasuk tipe iklim A, dengan nilai Q sebesar 2,6. Rata-rata bulan keringnya sebesar 0,3 dengan maksimumnya 2 dan dengan frekuensi sebesar 1 . Sedangkan rata-rata bulan basahnya sebesar 11,2 dengan maksimumnya 12 dan frekuensinya sebesar 8 . Besarnya curah hujan ratarata setiap tahun sebesar $3.552 \mathrm{~mm}$, dengan hari hujan sebanyak 187 hari. Suhu maksimum ratarata sebesar 30,10 C dan minimum rata-rata sebesar 20,100 C, sedangkan rata-rata kelembaban udaranya sebesar $88,33 \%$.

Berdasarkan data yang diperoleh dalam tahun 2014, Kelurahan Situ Gede mempunyai curah hujan yang cukup tinggi, seperti daerah Bogor lainnya, yaitu berkisar antara $3.500 \mathrm{~s} / \mathrm{d}$ $4.500 \mathrm{~mm} /$ tahun. Kelurahan-kelurahan di Bagian Bogor Barat mempunyai spesifikasi curah hujan rata-rata antara $3.500 \mathrm{~s} / \mathrm{d} 4.000 \mathrm{~mm} /$ tahun dan $4.000 \mathrm{~s} / \mathrm{d} 4.500 \mathrm{~mm} /$ tahun. Intensitas curah hujan minimum terjadi pada bulan April s/d Oktober antara $128 \mathrm{~s} / \mathrm{d} 345 \mathrm{~mm} / \mathrm{tahun}$. Temperatur udara di daerah Situ Gede dan sekitarnya, berkisar antara 260C s/d 34OC .

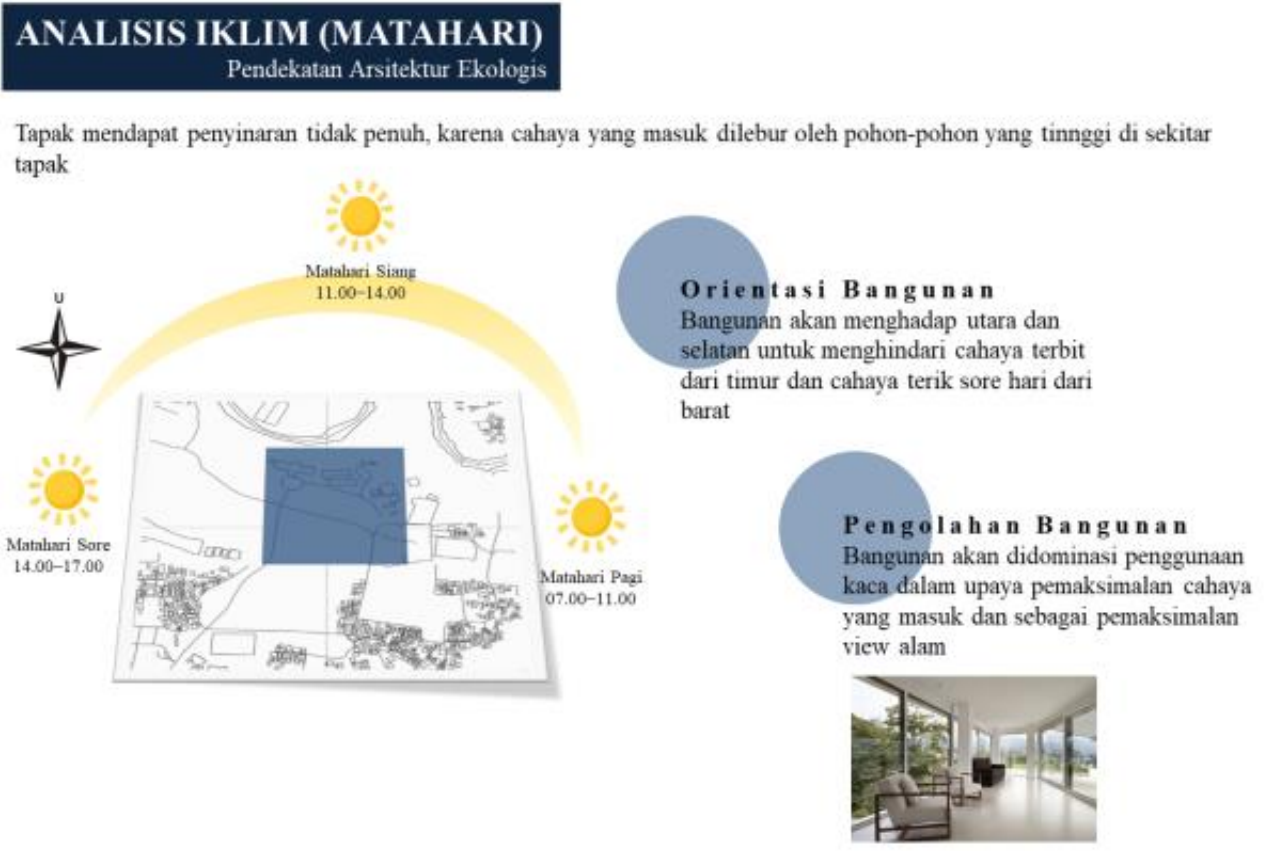

Gambar 5. Analisis Iklim (Matahari) 


\section{ANALISIS IKLIM (ANGIN)}

Pendekatan Arsitektur Ekologis

Angin pada tapak bertiup dari arah selatan tapak. Kondisi sekitar tapak yang dikelilingi hutan, membuat tapak mendapat penghawaan secara maksimal dan mendapat kualitas udara yang baik
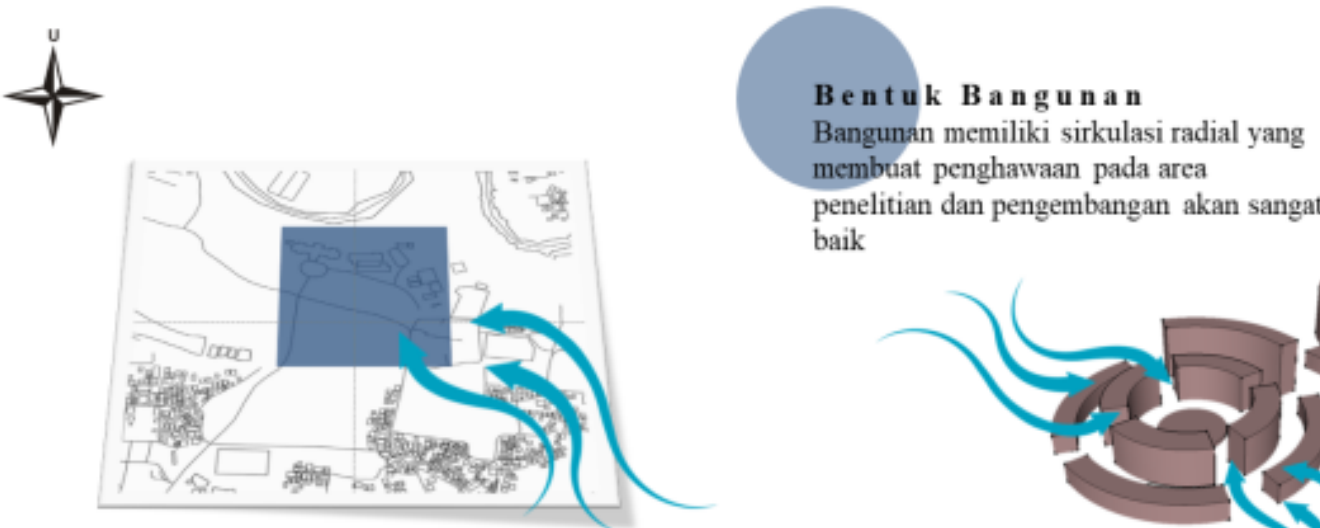

baik

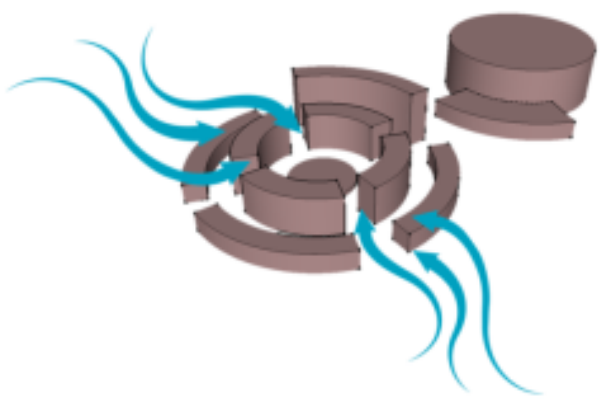

Gambar 6. Analisis Iklim (Angin)

\section{ANALISIS IKLIM (HIDROLOGI)}

Pendekatan Arsitektur Ekologis

Angin pada tapak bertiup dari arah selatan tapak. Kondisi sekitar tapak yang dikelilingi hutan, membuat tapak mendapat penghawaan secara maksimal dan mendapat kualitas udara yang baik

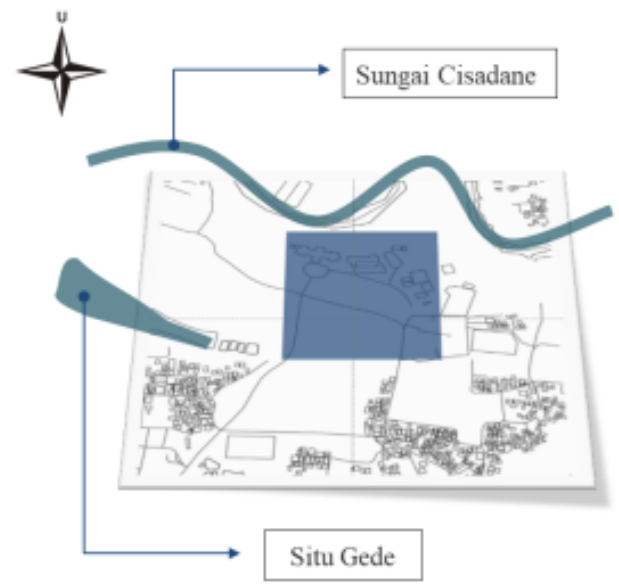

Kebutuhan Air Bersih

Kebutuhan air bersih sangat tersedia

karena dekat dengan sumber air yaitu

Sungai Cisadane dan juga Situ Gede

Gambar 7. Analisis Iklim (Hidrologi) 


\section{ANALISIS KEBISINGAN}

Sumber kebisingan terdekat berasal dari permukaan warga, tertapi kebisingan tersebut sangat rendah karena dibatasi oleh area hutan

$\stackrel{1}{p}$

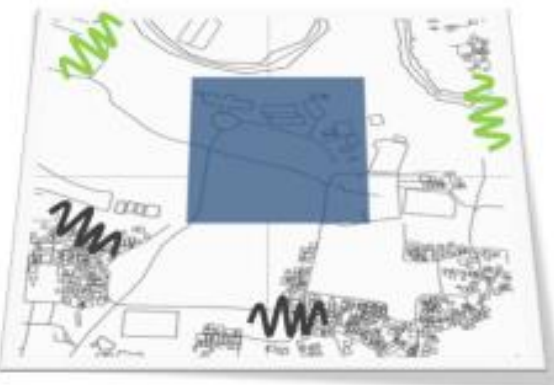

Aliran Sungai Cisadane pada area utara tapak dan posisi tapak yang berada di tengah hutan membuat suasana alami sangat terasa

Yu Tingkat kebisingan rendah

YM Tingkat kebisingan sedang

Gambar 8. Analisis Kebisingan

\section{KONSEP TRANSFORMASI BENTUK}

Transformasi bentuk menggunakan analogi matematis dari lingkaran tahun pada penampang pohon jati. Rasio tebal lapisan lingkaran tahun yaitu $2: 1,5: 1,3: 1,4: 1$ (Jurnal Pemuliaan Tanaman Hutan, 2020). Kondisi bentukan berupa lapisan lingkaran yang menumpuk dengan pola gelap terang sebagai acuan. Dari Bentukan awal tersebut kemudian ditranformasikan lagi menjadi 2 massa bangunan dengan salah satu massa dipotong sebagai sirkulasi.

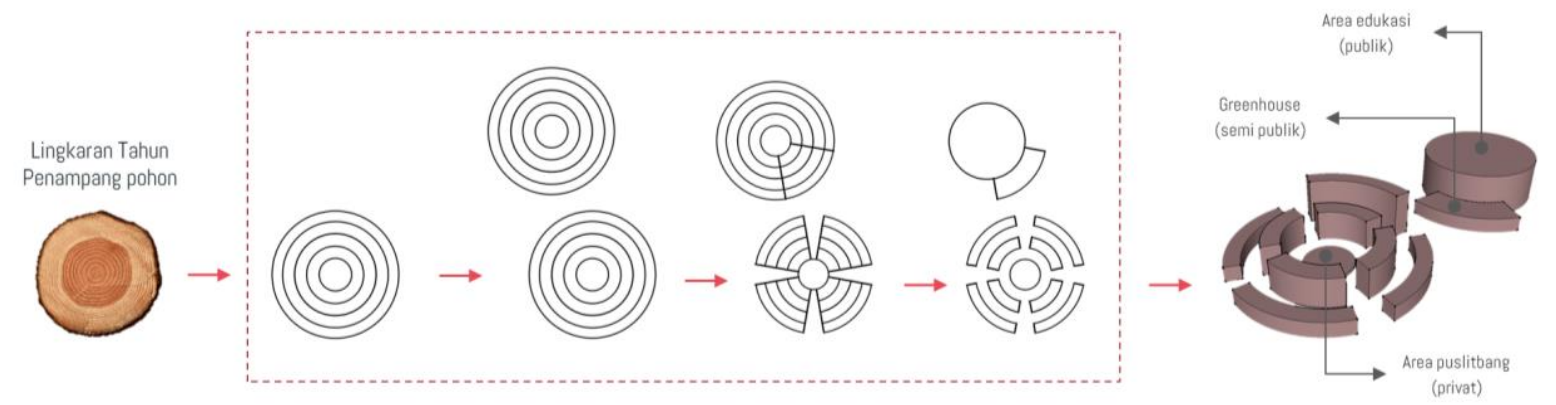

Gambar 9. Transformasi Bentuk

Tatanan ruang dalam Pada bangunan terdapat 2 area fungsi utama yaitu edukasi serta penelitian dan pengembangan. $\mathrm{P}$ ada area edukasi terdapat greenhouse, galeri, auditorium, resepsionis \& informasi, ruang pengawasan, ruang keamanan, area komersil, cafetaria, dan ruang servis. Pada area penelitian dan pengembangan terdapat laboratorium, kantor, resepsionis \& informasi, ruang pengawasan, ruang keamanan, area komersil, cafetaria, dan ruang servis. 


\section{DESAIN}

\section{Block Plan}

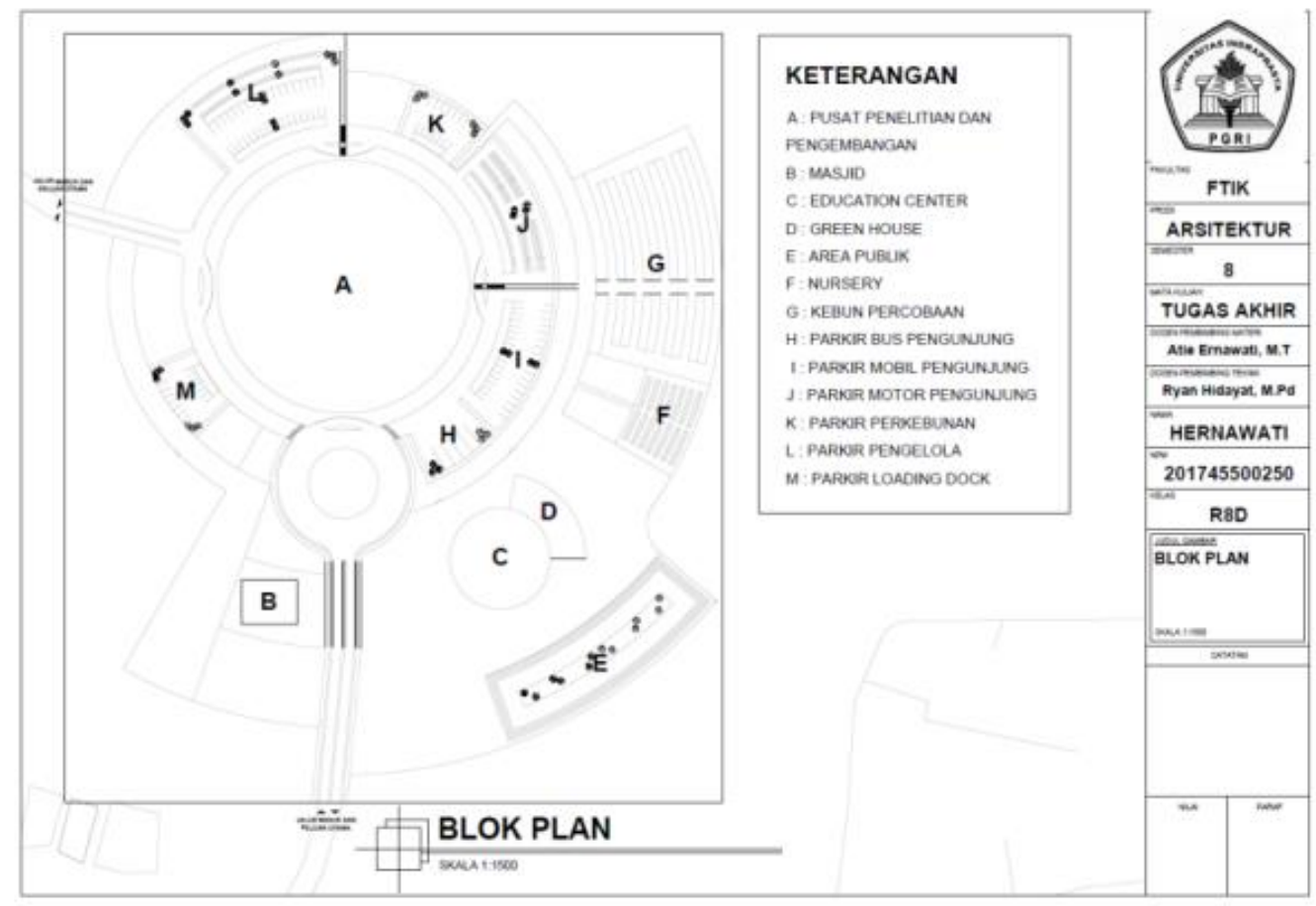

Gambar 10. Block Plan

\section{Site Plan}

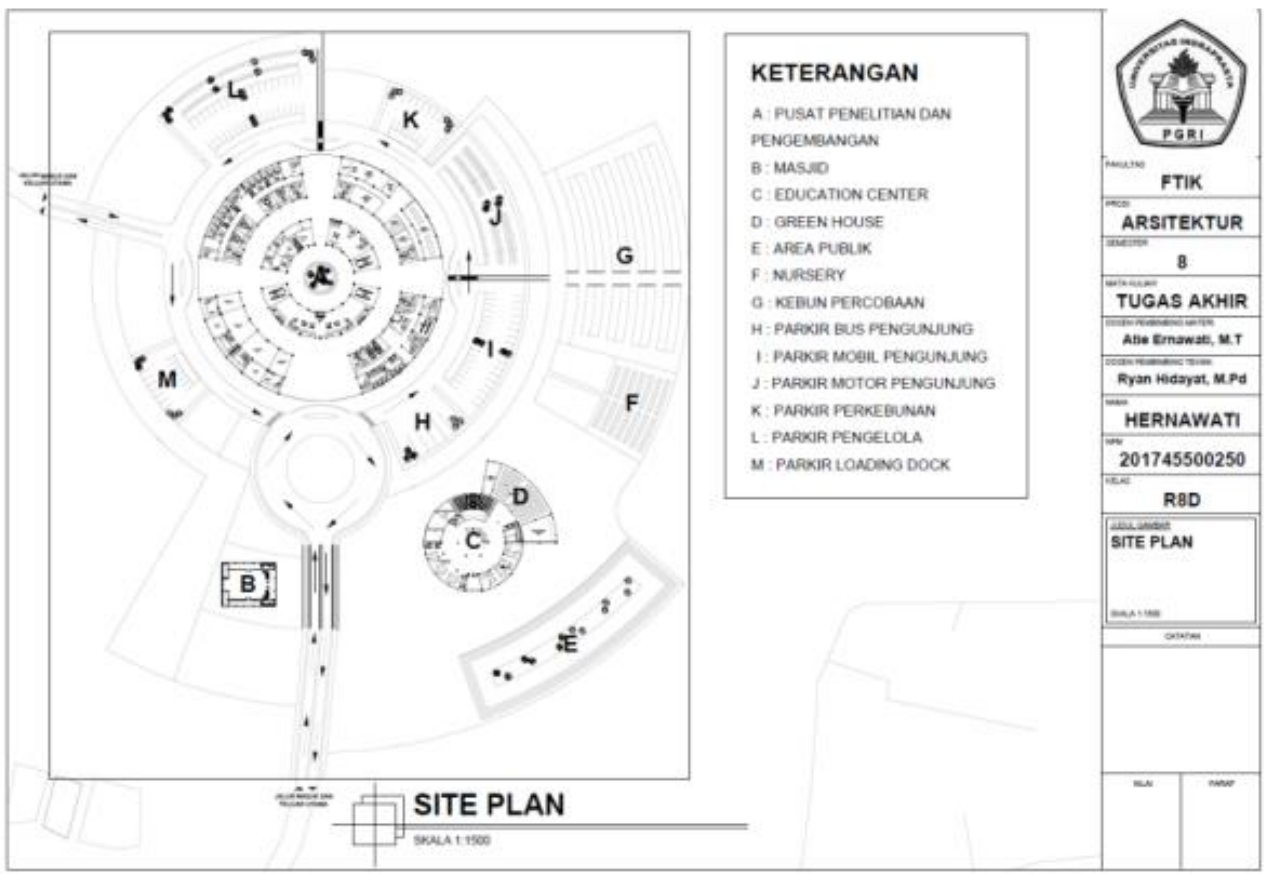

Gambar 11. Site Plan 
142 Perancangan Pusat Penelitian dan Pengembangan Tanaman Hutan Tropis Berbasis Edukasi di Kota Bogor

\section{Tampak Site}

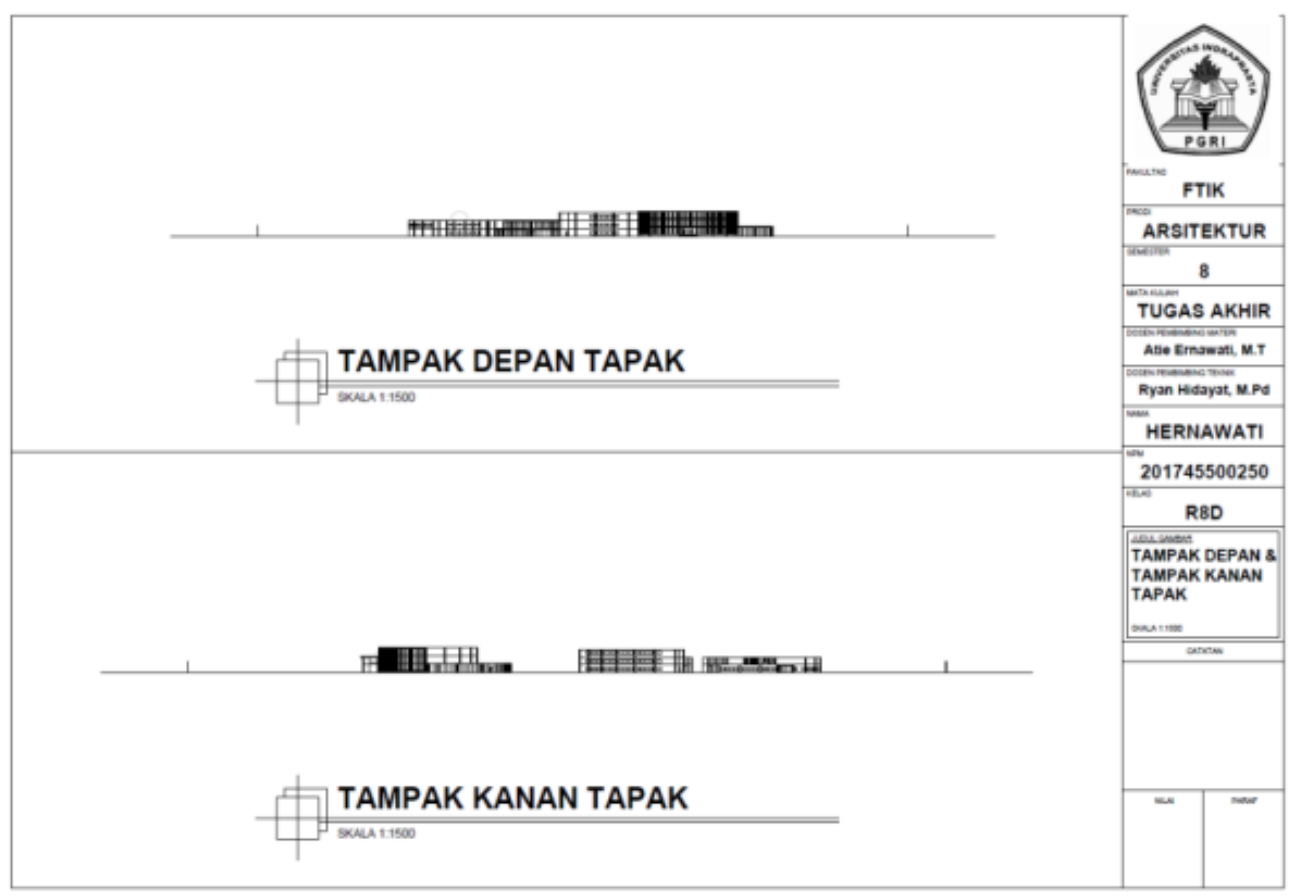

Gambar 12. Tampak Site

\section{Denah}



Gambar 13. Denah Lt.1 Puslitbang 


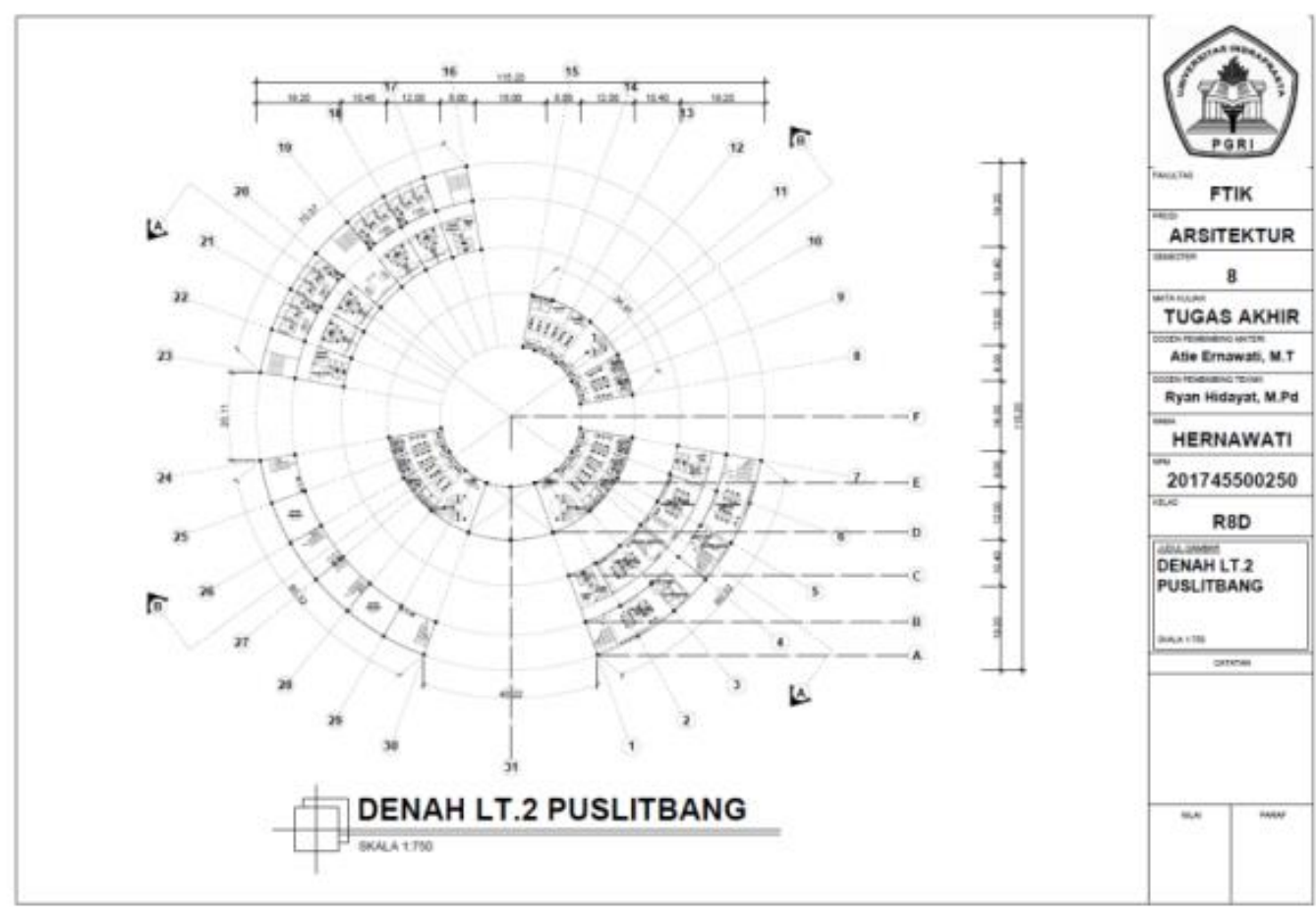

Gambar 14. Denah Lt.2 Puslitbang



Gambar 15. Denah Lt.3 Puslitbang 
144 Perancangan Pusat Penelitian dan Pengembangan Tanaman Hutan Tropis Berbasis Edukasi di Kota Bogor

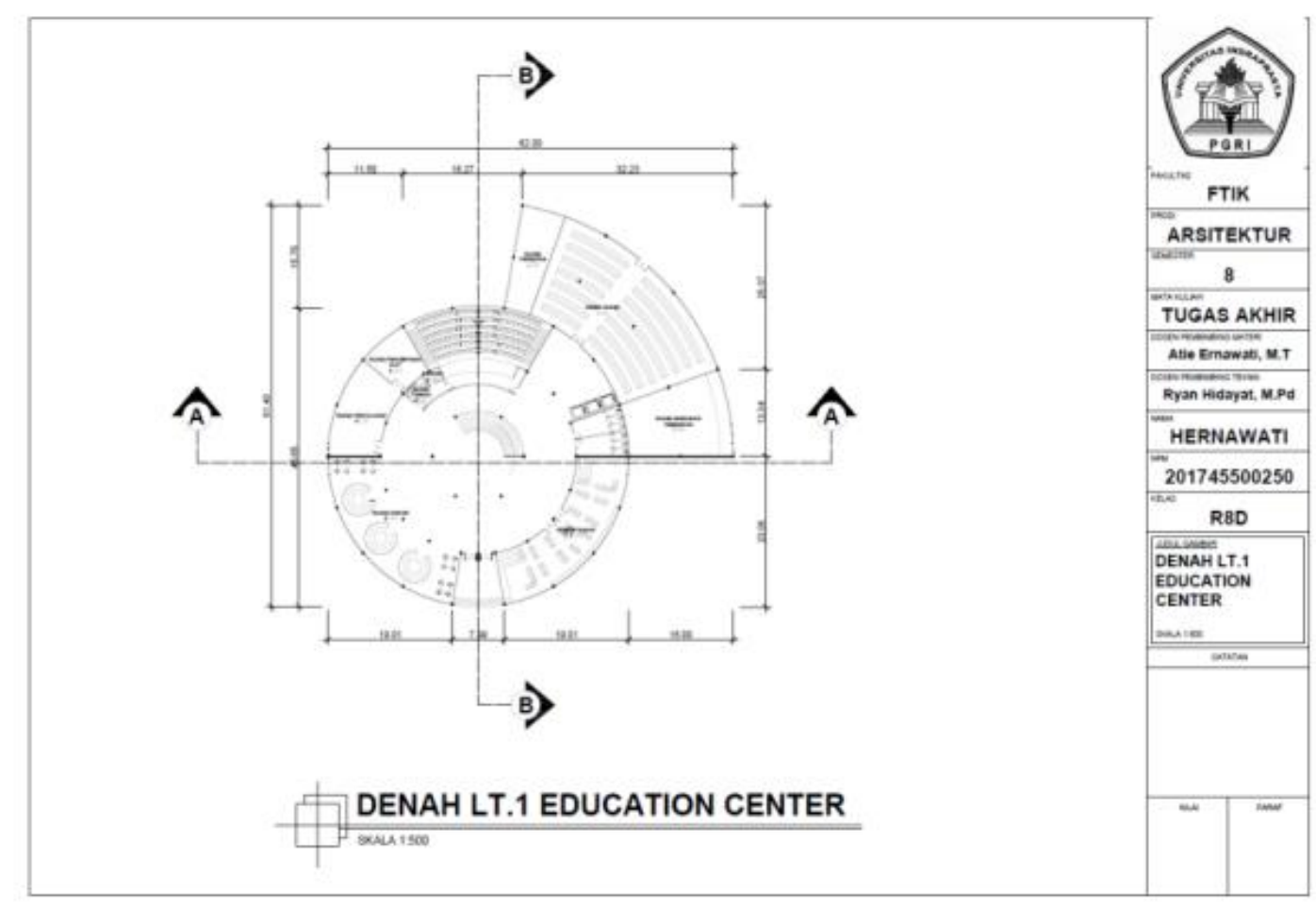

Gambar 16. Denah Lt.1 Education Center

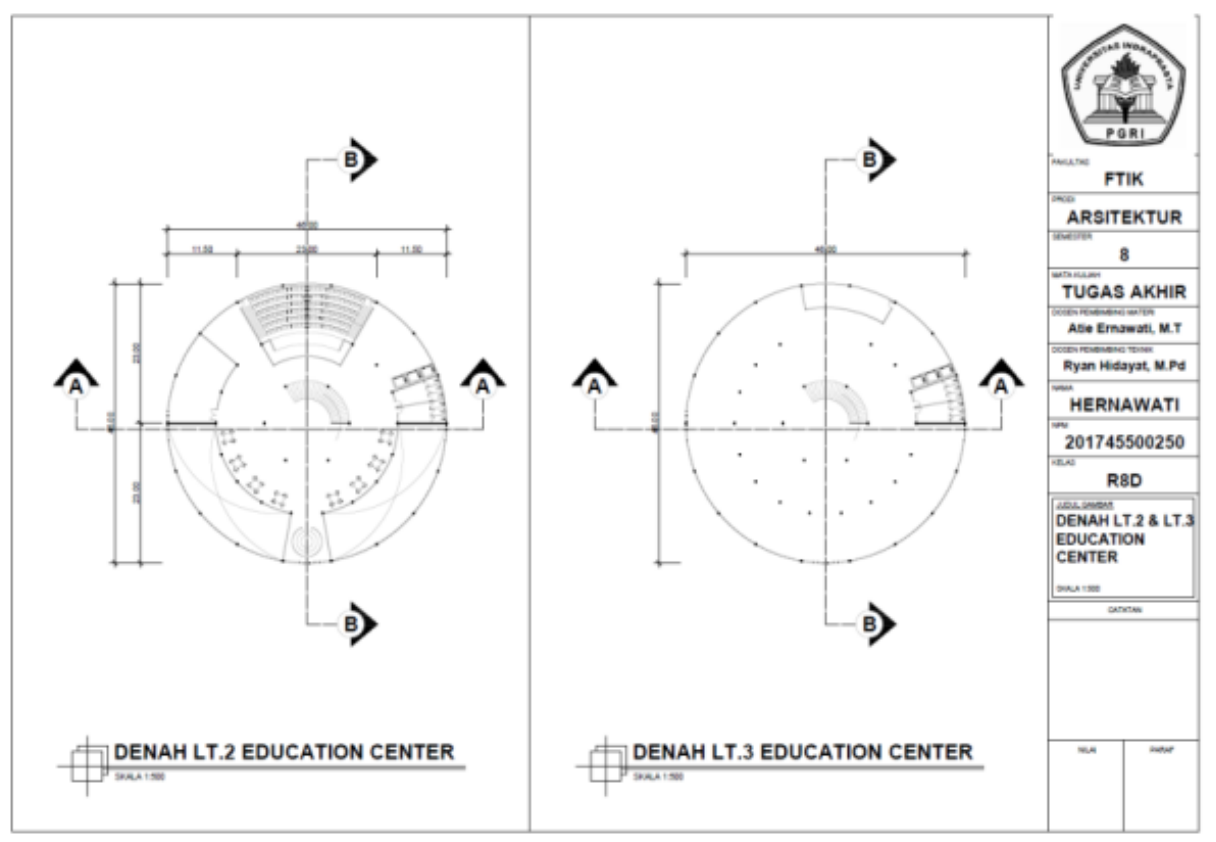

Gambar 17. Denah Lt.2 \& Lt.3 Education Center 


\section{Tampak}

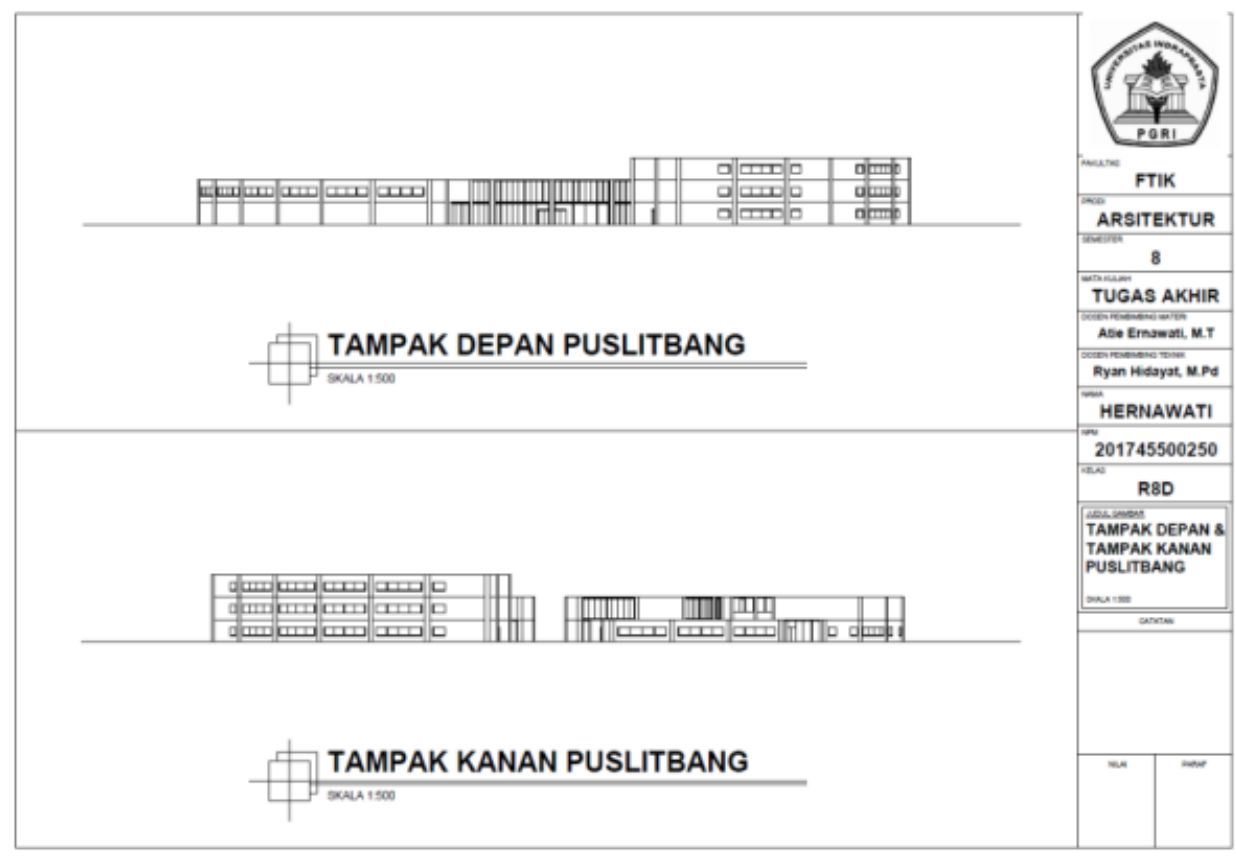

Gambar 18. Tampak Depan \& Kanan Puslitbang

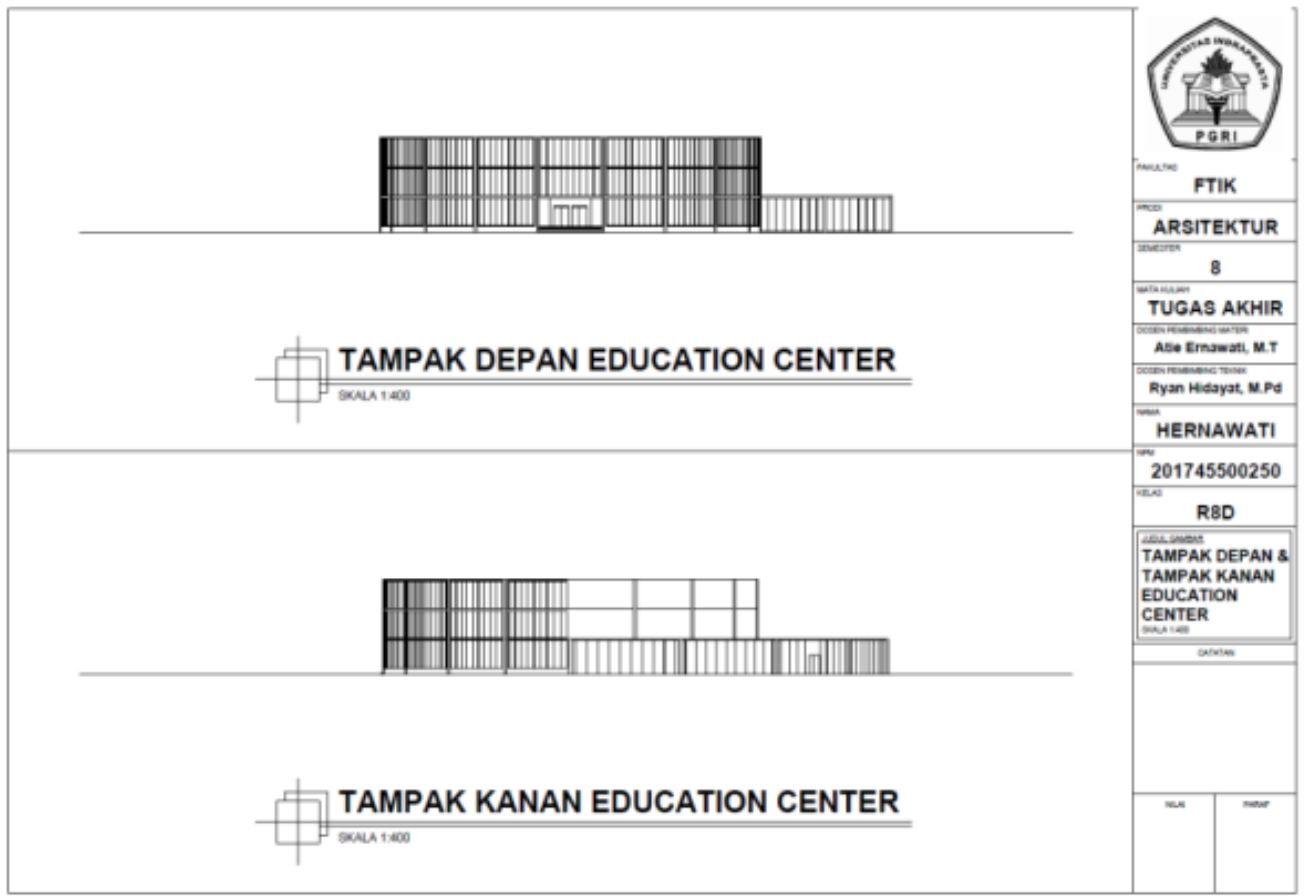

Gambar 19. Tampak Depan \& Kanan Education Center 
146 Perancangan Pusat Penelitian dan Pengembangan Tanaman Hutan Tropis Berbasis Edukasi di Kota Bogor

\section{Potongan}

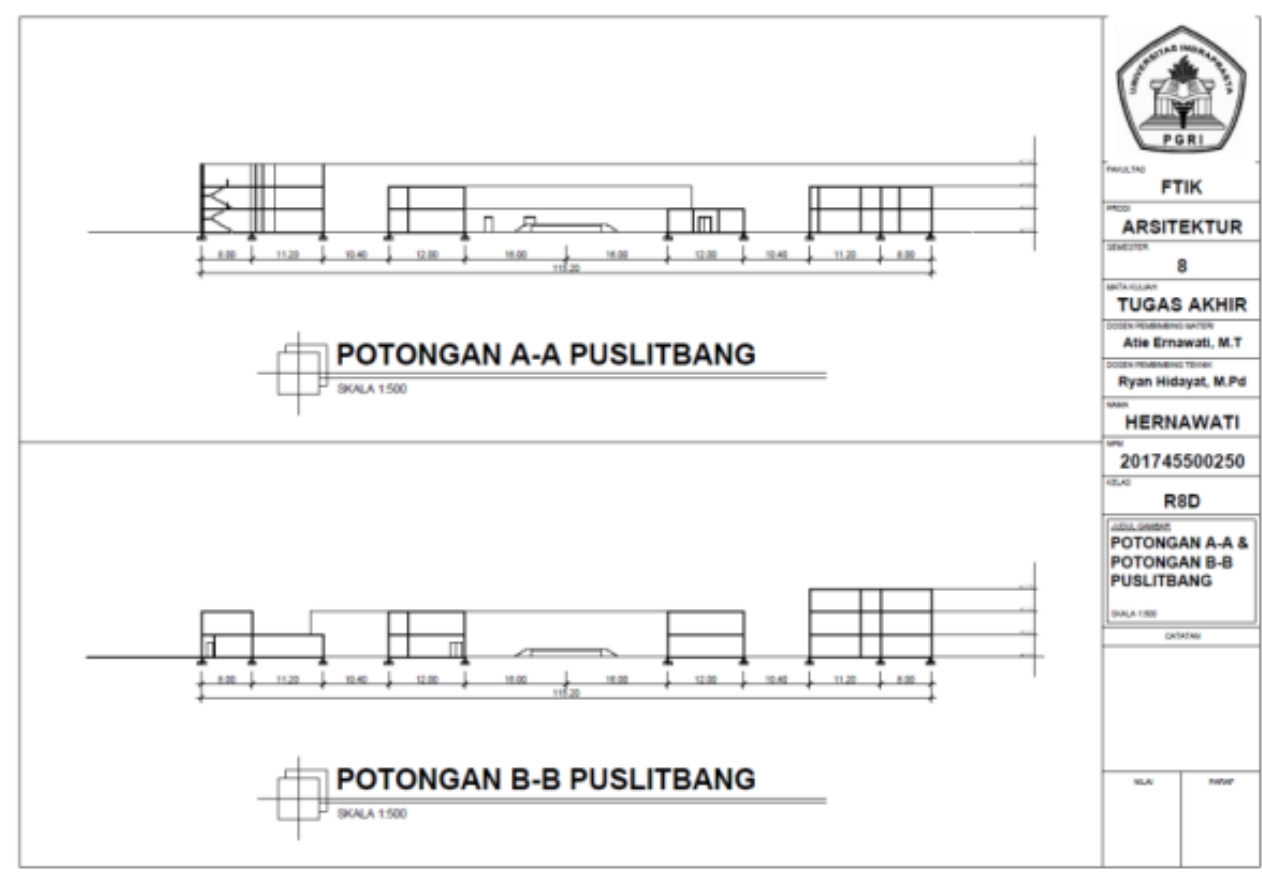

Gambar 20. Potongan Puslitbang

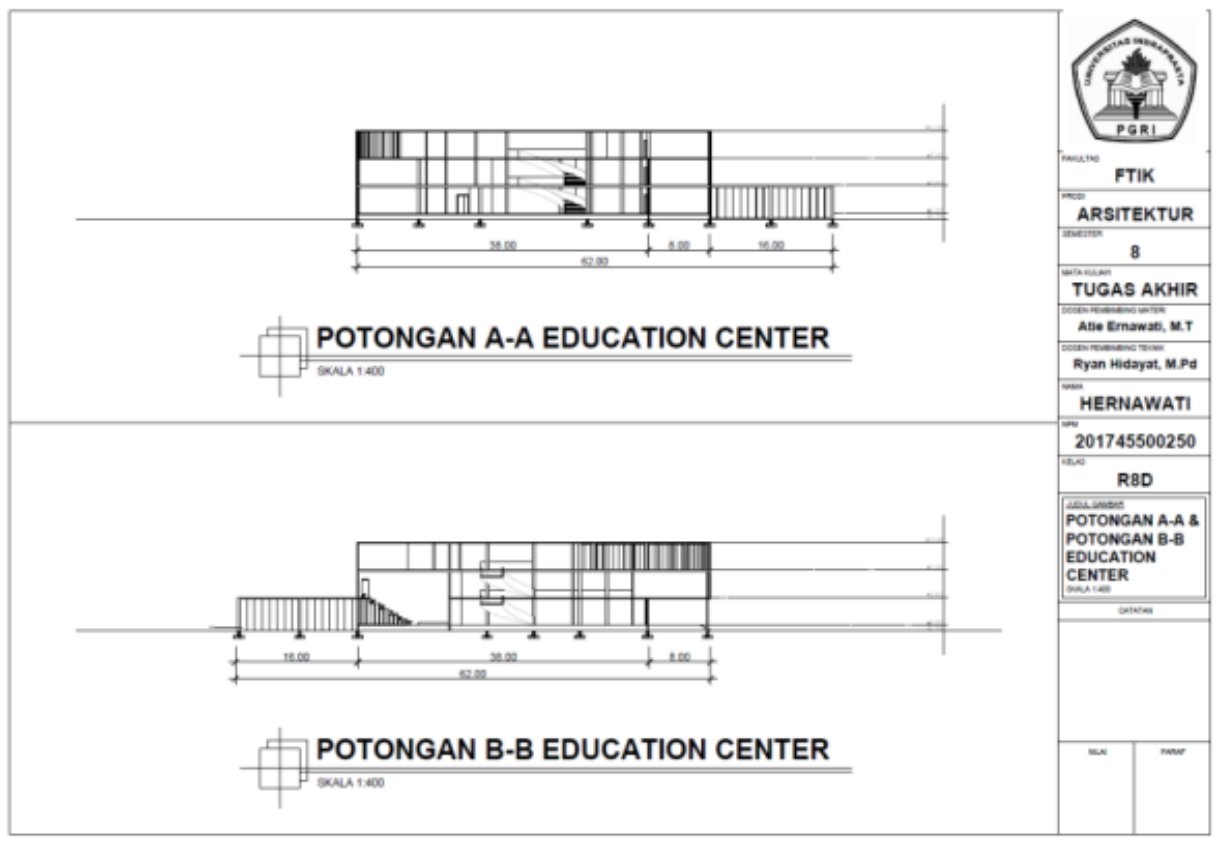

Gambar 21. Potongan Education Center 


\section{Perspektif}

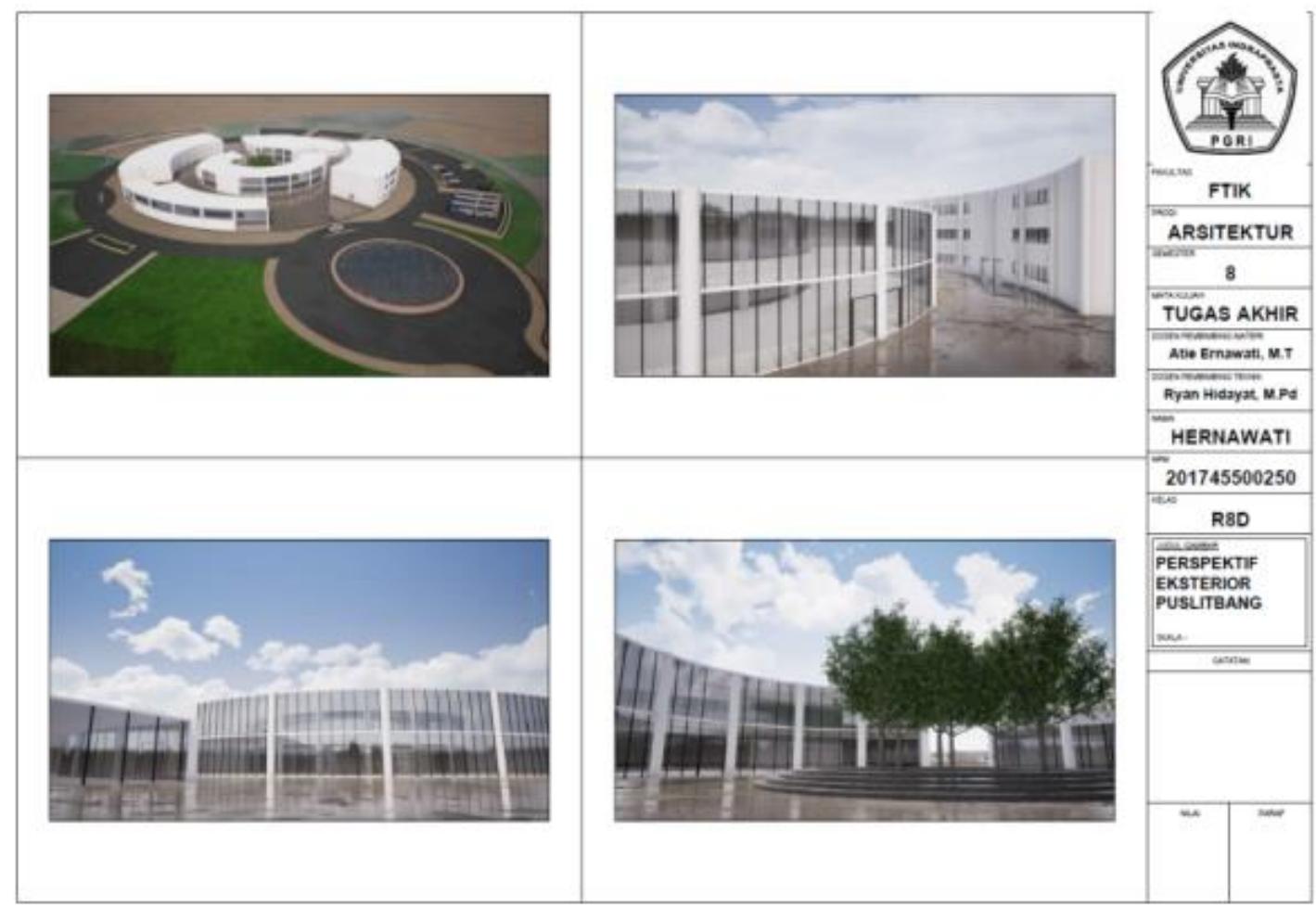

Gambar 22. Perspektif Eksterior Puslitbang

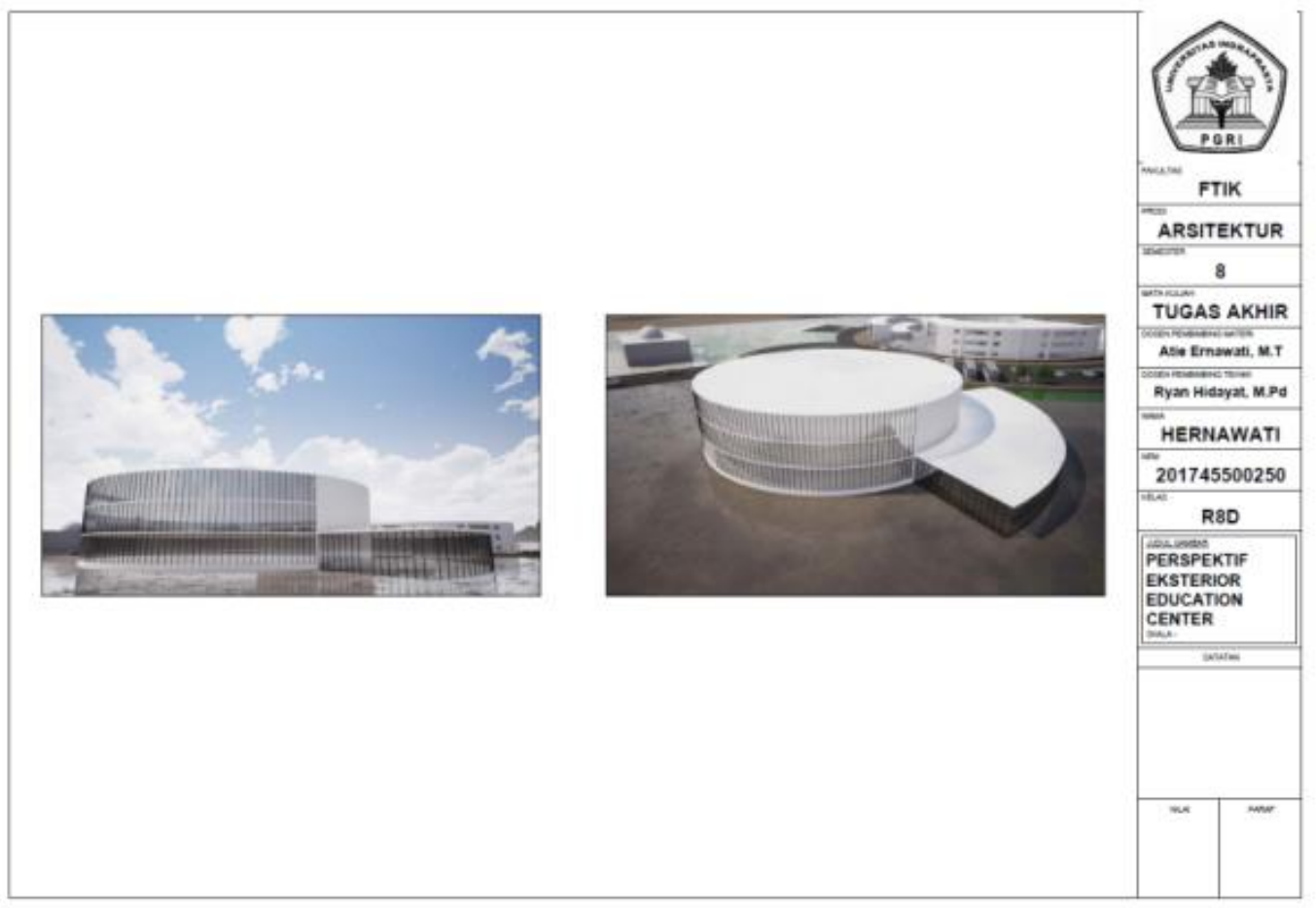

Gambar 23. Perspektif Eksterior Education Center 


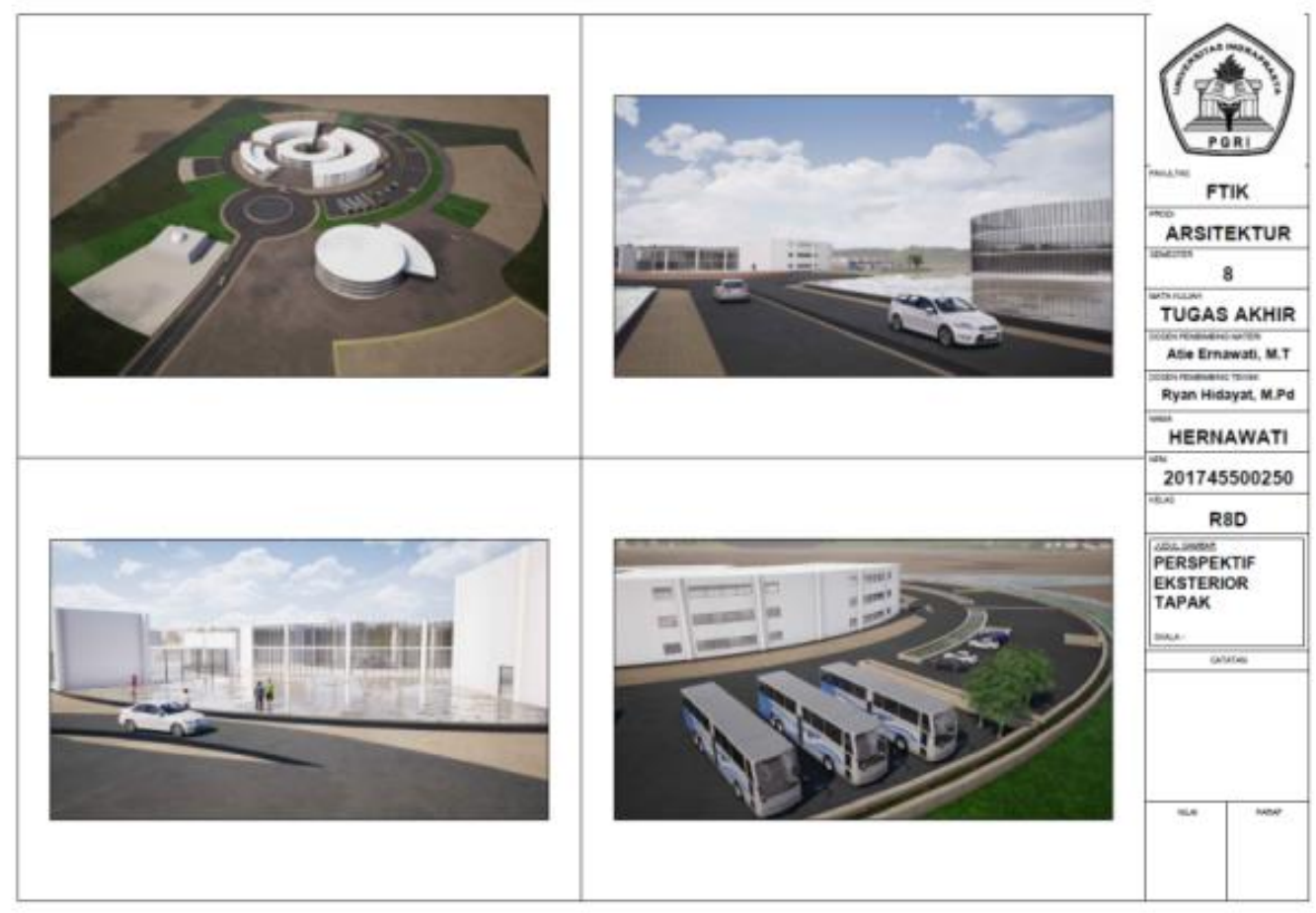

Gambar 24. Perspektif Tapak

\section{PENUTUP}

\section{Simpulan}

Kesimpulan yang didapat pada Perancangan Pusat Penelitian dan Pengembangan Tanaman Hutan Tropis Berbasis Edukasi, sebagai berikut:

1. Kebutuhan ruang pada Pusat Penelitian dan Pengembangan ini adalah dengan mempertimbangkan pengelompokan ruang berdasarkan fungsi utama yaitu research (riset/penelitian) dan education (edukasi).

2. Fasilitas edukasi yang ada di Pusat Penelitian dan Pengembangan ini dapat menjadi daya tarik eko wisata berbasis edukasi yang mendukung tentang kehutanan. Fasilitas edukasi dirancang khusus berupa education center (gallery, workshop, perpustakaan dan auditorium), public space dan juga tour sebagai kegiatannya.

3. Pusat Penelitian dan Pengembangan ini dirancang dengan pendekatan Arsitektur Ekologi agar dapat diterapkan prinsip-prinsip keselarasan lingkungan.

\section{Saran}

Pusat Penelitian dan Pengembangan tidak hanya ditujukan untuk penelitian. Tetapi juga dapat menjawab pertanyaan, apa dampak bangunan tersebut pada sekitar (lingkungan dan manusia). Bangunan penelitian harus bisa memberikan dampak kepada manusia mengenai kebutuhan informasi dan pengetahuan tentang kehutanan. Bangunan penelitian juga harus memberikan keselarasan terhadap lingkungan, dengan cara tidak merusak lingkungan dalam pembangunannya serta pengolahan limbah laboratorium yang baik. 


\section{DAFTAR PUSTAKA}

Adler, David (1999) Metric Handbook Planning and Design Data. Oxford Auckland Boston Johannesburg Melbourne New Delhi.

Leksono B, Kurinobu S, Ide Y. A Breeding strategy for the tropical eucalyptus: findings and lessons acquired from the multi-generation tree breeding of Eucalyptus pellita in Indonesia. Germany: Lambert Academic Publishing GmbH \& Co.KG; 2011

Fatahudin, Purwanto, Ru (2021). Jurnal Teknik Sipil dan Lingkungan. Perencanaan Perancangan Kawasan Ekowisata Situ Gede Kota Bogor, Vol. 06 No. 01

Menteri Lingkungan Hidup dan Kehutanan Republik Indonesia (2018). Peraturan Menteri Lingkungan Hidup dan Kehutanan Republik Indonesia

Mubarok, Muhammad Faiz (2019). Laboratorium Penelitian dan Pengembangan Tanaman Pangan di Kabupaten Semarang dengan Pendekatan Desain Arsitektur Organik. Universitas Negeri Semarang, Semarang.

Purwanto, Hadi (2000). Model Pusat Penelitian, Pengembangan dan Pemuliaan Benih Tanaman Hutan dengan Studi Kasus di Baturaden Purwokerto. Universitas Islam Indonesia, Yogyakarta.

Kurdi, Aserani (2010). Tanaman Herbal Indonesia: Cara Mengelola dan Manfaatnya bagi Kesehatan

Sari, Dela Nur Indah (2020). Perancangan Pusat Penelitian dan Pengembangan Tanaman Sayuran di Poncokusumo dengan Pendekatan Arsitektur Ekologis. Universitas Islam Negeri Maulana Malik Ibrahim, Malang.

Tamin, Anggraini, Ulfa (2017). Karya Abdi Masyarakat. Penyuluhan dan Pelatihan Eksplorasi Botani Hutan dalam Upaya Konservasi Hutan, Vol. 1

Umarputri, Rahardjo (2019). Jurnal Stupa. Pengelolaan Danau Situ Gede dan Hutan Penelitian Dramaga Sebagai Kawasan Ekowisata, Vol. 1, No. 2, hlm: 2239-2248 